\title{
Influence of Aminoethoxyvinylglycine (AVG) on Yield and Quality of Nut Crops from a Commercial Pecan Orchard
}

\author{
Bruce W. Wood \\ U.S. Department of Agriculture, Agricultural Research Service, Southeastern \\ Fruit and Tree Nut Research Laboratory, 21 Dunbar Road, Byron, GA \\ 31008-0087
}

Additional index words. aminoethoxyvinylglycine, growth regulator, fruit drop, abortion, alternate bearing, flowering, irregular bearing, profit, production, fruit retention, June drop, abscission

\begin{abstract}
Excessive fruit drop (i.e., June drop) can limit orchard profitability of certain pecan [Carya illinoinensis (Wangenh.) K. Koch] cultivars. The present study examines efficacy of aminoethoxyvinylglycine (AVG; formulated as ReTain ${ }^{\circledR}$; Valent BioSciences, Libertyville, IL), a natural ethylene inhibitor, for increasing nutmeat yield in a commercial 'Desirable' pecan orchard over a 2-year period. The 30-ha experiment consisted of two treatments (nontreated versus ReTain) in the first year, an "off" year in the orchard's alternate bearing cycle. The second year's study, an "on" year, consisted of four treatments (i.e., " 08 nontreated + 09 nontreated," "08ReTain + 09 nontreated," "08 nontreated + 09 ReTain," and "08ReTain + 09 ReTain"). AVG, as ReTain [132 mg. $\mathbf{L}^{-1}$ a.i. (11.7 oz/acre)], was applied as two post-pollination canopy sprays $\left(937 \mathrm{~L} \cdot \mathrm{ha}^{-1}\right) 2$ weeks apart in both years. During the "off" year, ReTain increased nut yield parameters with ReTain increasing kernel yield by $36 \%\left(704 \mathrm{~kg} \cdot \mathrm{ha}^{-1}\right.$ versus $\left.516 \mathrm{~kg} \cdot \mathrm{ha}^{-1}\right)$ over that of nontreated trees. In the subsequent "on" crop year, the trees exhibiting a ReTainassociated previous year yield increase of $\approx 36 \%$ exhibited a reduction in yield of $\approx 25 \%$, thus largely negating the previous season's yield increase over a 2-year alternate bearing cycle. Additionally, ReTain-treated trees during the "on" year failed to exhibit an increase in yield parameters over that of the nontreated control. As a result of a lag effect on subsequent year yield parameters, ReTain offers potential as a crop-load management tool for 'Desirable' orchards in "off" years such as a year of relatively high nutmeat price followed by a year of relatively low price. There appears to be no positive effect on yield when used in a heavy crop-load "on" year of an alternate bearing cycle. Thus, ReTain might have benefit for stabilizing alternate bearing in 'Desirable' pecan orchards. Kernel quality (defined as percentage of nut weight as kernel) of individual nuts from "on" year trees was not as sensitive to units of yield increase as for individual nuts of "off" year trees, thus implying that the rate of assimilate partitioning to individual reproductive structures in "off"-year trees is not as great as that in "on"-year trees.
\end{abstract}

Excessive early-season fruit drops can limit pecan orchard profitability. The most problematic drop is typically "Stage II drop," occurring $\approx 3$ to 5 weeks (usually by mid-June; i.e., June drop) after stigmas of pistillate flowers lose receptivity and fruit begin rapid elongation growth (Sparks and Madden, 1985). A primary cause of Stage II drop is associated with abnormal ovule development (i.e., integument, parenchymal nucleolus cell layers,

Received for publication 8 Dec. 2010. Accepted for publication 21 Jan. 2011.

The assistance of James Stuckey and Kirby Moncrief for data collection and that of Buck Paulk for providing access to trees, orchard management, harvesting, and nut processing and is gratefully acknowledged.

Use of trade names does not imply endorsement of the products named or criticism of similar ones not named.

e-mail bruce.wood@ars.usda.gov. embryo sac; Yates and Sparks, 1994, 1995); however, it is also potentially influenced by nutrient element nutrition at anthesis until a few weeks thereafter (Wood et al., 2010). Although Stage II drop is beneficial in excessively heavy crop-load years, it is undesirable when crop load is less than moderate. The magnitude of Stage II drop varies among cultivars, location, and years but is typically substantial for 'Desirable' - a major commercial cultivar grown in the southeastern United States.

Stage II drop links to ethylene physiology because treating fruit with ethylene can trigger fruit drop (Kays et al., 1975; Wood, 1983). Additionally, AVG \{Aminoethoxyvinylglycine [S]-trans-2-Amino-4-(2-aminoethoxy)-3-butenoic acid hydrochloride, a naturally occurring plant growth regulator produced by fermentation; formulated as ReTain at 15\% a.i.; EPA Reg. No. 73049-45; Valent BioSciences, Libertyville, IL \}, an ethylene inhibitor, can reduce or prevent drop in certain situations (Wood et al., 2009). AVG, formulated as ReTain, possesses potential as a horticultural tool for preventing or reducing unwanted fruit drop in pecan by interfering with endogenous ethylene biosynthesis, presumably by competitively inhibiting 1-aminocyclopropanecarboxylate synthase (Wood et al., 2010; Yu et al., 1979), the rate-limiting enzyme in the apparent primary ethylene anabolic pathway.

Wood et al. (2009) observed earlier that AVG, or ReTain, conditionally exhibits efficacy for reducing 'Desirable' fruit drop, thus justifying further evaluation in a real-world large commercial orchard environment. The value of AVG, or ReTain, as a horticultural tool in pecan horticulture depends on how the effects of increased fruit retention interact with pecan's natural "off-on" alternate bearing cycle (i.e., alternating cycles of few or no fruit followed by heavy fruit crops), which is driven in part by previous season crop load (Smith et al., 1993; Sparks, 1974; Wood, 2003; Wood et al., 2003). This article reports that use of AVG in commercial 'Desirable' orchards during "off" years is biologically efficacious, but use in heavy crop-load "on" years appears to be without benefit to either nut yield or quality.

\section{Materials and Methods}

Orchard characteristics. The study orchard was located near Valdosta, GA, a humid climatic zone. The site is lat. $31^{\circ} 07^{\prime} \mathrm{N}$, long. $-83^{\circ} 20^{\prime} \mathrm{W}$ at an elevation of $\approx+58 \mathrm{~m}$ $(190 \mathrm{ft})$ with a fine-loamy, siliceous, thermic Plinthic Kandiudults soil (TqA; Tifton loamysand). The test cultivar is 'Desirable' grafted to an open-pollinated 'Elliott' rootstock with test trees being $\approx 25$ years old. Experimental trees were spaced $15.24 \mathrm{~m} \times 15.24 \mathrm{~m}(50 \times 50 \mathrm{ft})$, on a square spacing, at 42.76 trees/ha (17.31 trees/ acre). The site has a freeze-free growing period of $\approx 280 \mathrm{~d}$ with annual precipitation of $\approx 1.3 \mathrm{~m}$ (51 inches).

Trees received subsurface drip irrigation with drip emitters rising to the soil surface at $1-\mathrm{m}$ intervals. Parallel irrigation lines run the length of tree rows positioned $\approx 1.2 \mathrm{~m}$ on either side of tree trunks. Drip emitters delivered water at $3.78 \mathrm{~L} \cdot \mathrm{h}^{-1}$ for $\approx 8$ to $12 \mathrm{~h} \cdot \mathrm{d}^{-1}$, depending on water needs, throughout the growing season. Irrigation lines were within a herbicide strip maintained along the tree row in a bare state using glyphosate (Monsanto, St. Louis, MO). Trees received annual broadcast applications of nitrogen, potassium (K), phosphorous, magnesium, and calcium as needed based on previous July leaf analysis at principal leaf development growth stage "11" (Finn et al., 2007). Canopies also received foliar sprays of micronutrients (zinc, nickel, copper, manganese, iron, and boron) during canopy expansion (growth stage 11 to 17) each spring. Fertilizer application rates were determined based on July-sampled leaf analysis from the previous season. Orchard management included routine foliar sprays of pesticides to control pecan scab (Fusicladosporium effusum) disease and various arthropod pests, as prescribed by the Georgia Extension Service 
(Hudson et al., 2007). Pest management practices produced nuts with little or no pecan scab damage and little or no fruit drop or fruit damage as a result of pathogen or arthropod pests.

Experimental design. This experiment tested the hypothesis that canopy sprays of an even-aged 'Desirable' orchard in either "off" (2008) or "on" (2009) years with ReTain increases nut yield. Because real-world non-hedge-pruned pecan orchards are biennially cyclical in bearing, the present study was set up to test ReTain's efficacy over a 2-year period in a cycling orchard beginning with an "off" year (2008, the first year of study) and followed by an "on" year (2009, the second year of study). The overall orchard crop load was moderate ( $\approx 40 \%$ of shoots fruiting) during the "off" year and was heavy (with $\approx 70 \%$ of terminals fruiting) in the second year of study-i.e., the "on" year of the biennial cycle.

Experimental design consisted of two treatments during the "off" year (i.e., 2008) and four treatments during the "on" year (i.e., 2009). "Off"-year treatments were: nontreated (i.e., no ReTain control) and ReTain-treated, coded hereafter as "nontreated control" and "ReTain," respectively. ReTain's efficacy was assessed by application at $132 \mathrm{mg} \cdot \mathrm{L}^{-1}$ a.i. through an air-blast sprayer at $937 \mathrm{~L} \cdot \mathrm{ha}^{-1}$ (11.7 oz a.i./acre) on each of the two application dates. Silwet L-77, an organosilicone surfactant (Helena Chemical Co., Memphis, TN), was tank-mixed with ReTain at $0.025 \% \mathrm{v} / \mathrm{v}$. The study was structured in a 10 replicate randomized complete block design using 30 -tree replicates $(n=20$; i.e., two treatments). Treatment plots were separated by a buffer row of nontreated trees. Thus, the experiment used roughly 30.35 ha (75 acres) of trees. During the second year, the two previous year treatment plots were divided in half to provide four treatments: nontreated in 2008 and nontreated in 2009 $(08 \mathrm{NT}+09 \mathrm{NT})$, nontreated in 2008 and ReTain in 2009 (08NT + 09R), ReTain in 2008 and nontreated in $2009(08 \mathrm{R}+09 \mathrm{NT})$, and ReTain in 2008 and ReTain in 2009 (08R + 09R). The first ReTain application in both years was $\approx 2$ to $3 \mathrm{~d}$ after the last receptive staminate flowers had lost receptivity, and the second application was $\approx 2$ weeks after the first. Thus, in the second year, the study was structured in a 10 replicate randomized complete block design using 15 -tree plots $(n=40$; i.e., four treatments).

Response variables were in-shell nut yield and total nutmeat (i.e., kernel) yield (both per tree and per unit area of orchard), percentage of kernel (percentage proportion of nutmeat weight to total nut weight), percentage of kernels that are marketable (kernels meeting minimal quality parameters), and weight of marketable kernels per tree and unit of orchard area. In-shell and nutmeat yield, and kernel quality, for each experimental unit was based on mechanically shaking trees when at least $90 \%$ of attached fruit exhibited shuck-split. Plots were once-over harvested with plot nut weights (Wheel Load Weight Scales Model
PT300; Intercomp, Minneapolis, MN) recorded in the field for in-shell nuts, and nut samples $(2 \mathrm{~kg})$ taken for determination of percentage kernel and marketable kernel and trash. Marketable kernel weight was based on exclusion of excessive dark-colored, distorted, wafered, or fuzzed kernels. Statistical analysis was performed on parameters measured for nonbulked samples (i.e., individual plots) by two-way least squares analysis of variance (ANOVA) at $P \leq 0.05$. Mean separation for main effects and interaction was by two-way least squares ANOVA at $P \leq 0.05$ using Tukey's honestly significant difference test (SAS Institute Inc., Cary, NC). Additionally, in-shell nuts were bulked by each of the four treatments and processed through a commercial cleaning plant to remove trash and lightweight nuts (i.e., pops and poorly filled) for determination of total commercial clean weight of nuts per treatment. Statistical analysis was not performed on bulked cleaning plant data.

\section{Results}

First-year: Influence of ReTain on nut yield and quality in an "off" year when trees were not previously exposed to ReTain. ReTain's application to a commercial 'Desirable' pecan orchard in an "off" year increased same-year in-shell nut yield on both an individual tree and unit area basis (Table 1). ReTain treatment increased individual tree inshell yield to $32.2 \mathrm{~kg} /$ tree, or a $45 \%$ increase over nontreated control trees. Similarly, unit area in-shell yield was $1375 \mathrm{~kg} \cdot \mathrm{ha}^{-1}$, or a $45 \%$ increase over nontreated control trees. Although percentage kernel trended higher in the nontreated control at $54.4 \%$ versus $53.0 \%$ over the ReTain treatment, the difference was not statistically significant at $P=0.05$. Similarly, marketable kernel yield per tree was $16.5 \mathrm{~kg} /$ tree, or a $56 \%$ increase over that of the nontreated control at $12.1 \mathrm{~kg} /$ tree. On a unit area basis, ReTain produced $704 \mathrm{~kg} \cdot \mathrm{ha}^{-1}$, or $36 \%$ greater nutmeat yield than that of the nontreated control. This measured yield difference was validated by bulked yields of nuts processed through the commercial cleaning plant, where there was a $46 \%$ meat increase resulting from ReTain. Thus, during the first year of use in a moderately "off" year, ReTain substantially increased yield of 'Desirable' pecan trees under real-world commercial orchard conditions.

Second-year: Influence of ReTain on yield and quality in an "on" year after previous

Table 1. First-year influence of ReTain on yield and quality of 'Desirable' pecan during an "off" light crop-load year.

\begin{tabular}{lcccccc}
\hline & $\begin{array}{c}\text { In-shell } \\
(\mathrm{kg} / \text { tree })\end{array}$ & $\begin{array}{c}\text { In-shell } \\
\left(\mathrm{kg}^{\left.-h^{-1}\right)}\right.\end{array}$ & $\begin{array}{c}\text { Kernel }(\%) \\
\text { Kreatment }\end{array}$ & $\begin{array}{c}\text { Kernels } \\
(\mathrm{kg} / \text { tree })\end{array}$ & $\begin{array}{c}\text { Total } \\
\text { kernels } \\
\left(\mathrm{kg} \cdot \mathrm{ha}^{-1}\right)\end{array}$ & $\begin{array}{c}\text { Cleaning plant } \\
\text { kernel yield } \\
\left(\mathrm{kg} \cdot \mathrm{ha}^{-1}\right)\end{array}$ \\
\hline Nontreated control & $22.2 \mathrm{~b}^{\mathrm{y}}$ & $948 \mathrm{~b}$ & $54.5 \mathrm{a}$ & $12.1 \mathrm{~b}$ & $516 \mathrm{~b}$ & 500 \\
ReTain & $32.2 \mathrm{a}$ & $1375 \mathrm{a}$ & $53.0 \mathrm{a}$ & $16.5 \mathrm{a}$ & $704 \mathrm{a}$ & 728 \\
\hline
\end{tabular}

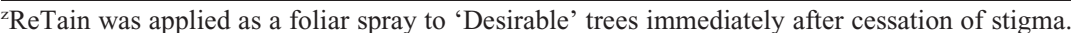

${ }^{y}$ Data analyzed by least squares analysis of variance, $P \leq 0.05$; means within a column followed by different letters are statistically different by Student's $t$ test.

${ }^{\mathrm{x}}$ Total kernel yield, or meat yield, is based on bulk cleaning of nuts at a commercial cleaning plant to blow out trash and light nuts, and kernel percentage is also determined from a bulk sample at the plant; thus, statistical analysis of treatment differences is not possible because there is only one sample per treatment. 
Table 2. Influence of ReTain on yield and quality parameters as influenced by previous year ReTain treatment.

\begin{tabular}{|c|c|c|c|c|c|c|c|c|}
\hline Treatment $^{2}$ & $\begin{array}{c}\text { In-shell } \\
\text { yield } \\
\text { (kg/tree) }\end{array}$ & Kernel (\%) & $\begin{array}{c}\text { Total } \\
\text { kernels } \\
\text { (kg/tree) }\end{array}$ & $\begin{array}{c}\text { Total } \\
\text { kernels } \\
\left(\mathrm{kg} \cdot \mathrm{ha}^{-1}\right)\end{array}$ & $\begin{array}{c}\text { Marketable } \\
\text { kernels }^{x}(\%)\end{array}$ & $\begin{array}{c}\text { Marketable } \\
\text { kernels } \\
(\mathrm{kg} / \text { tree })\end{array}$ & $\begin{array}{c}\text { Marketable } \\
\text { kernels } \\
\left(\mathrm{kg} \cdot \mathrm{ha}^{-1}\right)\end{array}$ & $\begin{array}{c}\text { Cleaning plant } \\
\text { meat yield } \\
\left(\mathrm{kg} \cdot \mathrm{ha}^{-1}\right)\end{array}$ \\
\hline Nontreated 2008 and nontreated 2009 & $75.4 \mathrm{a}^{\mathrm{w}}$ & $50.5 \mathrm{a}$ & $38.0 \mathrm{a}$ & $1624 \mathrm{a}$ & $84.2 \mathrm{a}$ & $74.9 \mathrm{a}$ & $1297 \mathrm{a}$ & 1383 \\
\hline Nontreated 2008 and ReTain in 2009 & $72.6 \mathrm{a}$ & $51.1 \mathrm{a}$ & $37.0 \mathrm{a}$ & 1579 a & $82.5 \mathrm{a}$ & $68.4 \mathrm{a}$ & $1185 \mathrm{a}$ & 1339 \\
\hline ReTain in 2008 and ReTain in 2009 & $54.4 \mathrm{~b}$ & $51.0 \mathrm{a}$ & $27.8 \mathrm{~b}$ & $1186 \mathrm{~b}$ & $79.0 \mathrm{a}$ & $51.5 \mathrm{~b}$ & $890 \mathrm{~b}$ & 1004 \\
\hline
\end{tabular}

${ }^{\mathrm{z}}$ ReTain was applied as a foliar spray to 'Desirable' trees immediately after cessation of stigma receptivity and again 2 weeks later. ReTain was applied at 132 $\mathrm{mg} \cdot \mathrm{L}^{-1}$ a.i. at $937 \mathrm{~L} \cdot \mathrm{ha}^{-1}(11.7 \mathrm{oz} / \mathrm{acre})$. In 2009 , “on"-year trees had a heavy crop of $\approx 2016 \mathrm{~kg} \cdot \mathrm{ha}^{-1}$ (1800 lbs/acre) in-shell and a previous year's (2008) moderate crop (i.e., "off", year). Experimental design consisted of four treatments (ReTain in '08 + ReTain in '09; nontreated in ' $08+$ nontreated in '09; ReTain in '08+ nontreated in '09; nontreated in '08 + ReTain in '09). The entire study consisted of roughly 30.35 ha (75 acres) of trees.

${ }^{\mathrm{y}}$ Marketable kernels are defined as those remaining after exclusion of excessive dark, shriveled, fuzzy, or blotched nutmeats.

${ }^{\mathrm{x}}$ Meat yield based on bulk cleaning of nuts at a commercial cleaning plant to blow out trash and light nuts and kernel percentage determined in bulk sample at the plant; thus, statistical analysis of bulked treatment differences is not possible because only one sample was taken.

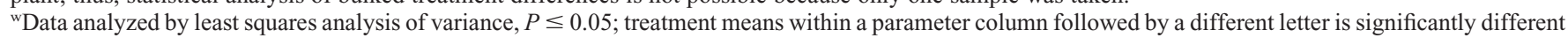
at $P=0.05$ using Tukey's honestly significant difference test.

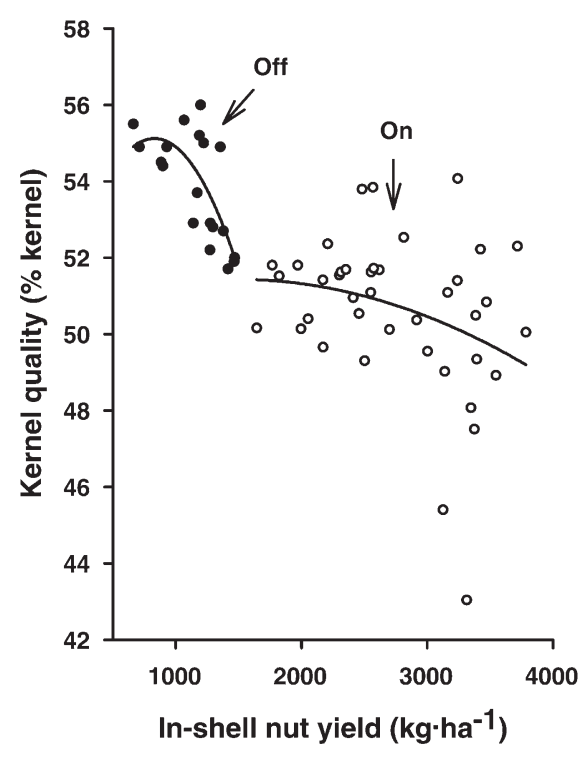

Fig. 1. Influence of crop size on kernel quality of 'Desirable' pecan in an "off" and "on" year. Regressions include percentage kernel for all plot data of all treatments within each of the "on" and "off" years. Quadratic regression for "percentage kernel" in an "off" year $=4.982+$ $1.274^{\mathrm{e}-1} x-7.666^{\mathrm{e}-6} x^{2}\left(R^{2}=0.52, \alpha=0.05\right) " ;$ percentage kernel in an "on" year $=5.052+$ $1.237^{\mathrm{e}-3} x-4.195^{\mathrm{e}-7} x^{2}\left(R^{2}=0.09, \alpha=0.05\right)$.

It is noteworthy that although AVG might possibly delay shuck split of ripe fruit through its effect on ethylene, the roughly 12-week period between AVG application and fruit ripening was enough to have no detectable effect on shuck split (based on visual observations).

\section{Discussion}

The ability of AVG, as ReTain, to enhance pecan fruit retention is consistent with similar effects on certain walnut (Juglans regia L. cv. Serr) cultivars (Anderson et al., 2006; Beede and Polito, 2003; Buchner et al., 2006) and certain other tree or vine fruit crops (Belding and Lokaj, 2002; Bregoli et al., 2002; Byers, 1997, 1998a, 1998b; Clayton et al., 2000; Dal-Cin et al., 2008; Greene, 2002, 2005, 2006; Greene and Schupp, 2004; Hayama et al., 2008; Hu et al., 2002; Rath et al., 2006; Salazar-Garciìa et al., 2006; Schupp and Greene, 2004; Shafer et al., 1997; Webster et al., 2006; Williams, 1980). The product may therefore exhibit potential as a horticultural tool for crop load management in pecan (Wood et al., 2009). ReTain's ability to block ethylene biosynthesis, and therefore potentially inhibit Stage II fruit drop in pecan, is consistent with ethylene playing a key role in the abortion of developing pecan fruit, as has been previously implicated (Kays et al., 1975; Wood, 1983).

The present large field study confirms a previous observation (Wood et al., 2009) that ReTain can increase fruit retention of 'Desirable' pecan sufficient to substantially increase nutmeat yield in certain years; however, the current study indicates that its efficacy as a horticultural tool for crop-load management is questionable in a relatively heavy "on" crop-load year after use in a previous "off" year. The ReTain-associated $\approx 36 \%$ increase in marketable meat yield per unit area of orchard observed in a moderate "off" year was not replicated in the subsequent heavy "on" year when ReTain was again used. Thus, ReTain's efficacy for 'Desirable' is greatly influenced by crop load and possibly by other factors (e.g., status of nutrient element physiology; Wood et al., 2009, 2010). It is important to note that trees receiving ReTain in an "off" year produced less in-shell, total kernel, marketable kernels per unit orchard area in the subsequent "on" year than did the nontreated control. This outcome is opposite that observed in a relatively small preliminary ReTain study in which a single application did not decrease nut yield in an "on" year after the year of treatment and ReTain treatments increased fruit retention in moderate to heavy crop-load trees but not in light crop-load trees (Wood et al., 2009; where inshell nut yield was 46 to $64 \mathrm{~kg} /$ tree in the "on" treatment year and 26 to $29 \mathrm{~kg}$ /tree in the subsequent "off" treatment year). The lack of effect in an "on" year in the present study is likely the result of unknown interacting factors rather than ReTain's inability to affect abscission-associated ethylene metabolism.

This indicates that besides crop load, there might be one or more additional interacting factors affecting ReTain's efficacy for increasing nut or nutmeat yield. Anecdotal evidence indicates that this might be early-season fruit K status (Wood et al., 2010). The aforementioned preliminary study (Wood et al., 2009) was in an orchard where young fruit were K-deficient (i.e., meeting the $\mathrm{K}$ sufficiency threshold for foliage but not meeting a higher $\mathrm{K}$ sufficiency threshold for young fruit; Wood et al., 2010) for the first few weeks post-ovule fertilization. Another possible interacting factor often touted by growers and extension specialists is an excessive number of pollen grains reaching the stigmatic surface of flowers during an "on" year, which can in turn trigger fruit abortion. Perhaps ReTain was unable to reduce adequately the ethylene surge that is associated with putative excessive pollen exposure. Excessive pollen appears to be the primary cause of a similar drop in walnut, in which case ReTain's use substantially increases fruit retention and nut yield (Anderson et al., 2006; Beede and Polito, 2003; Buchner et al., 2006). The relatively light pollen load in this 'Desirable' orchard during the "off" year (when ReTain was efficacious) and the heavy pollen load during the "on" year (when ReTain failed to exhibit efficacy) is suggestive that, at least in this case, excessive pollination was an unlikely interacting factor.

It is noteworthy that each unit increase in yield confers less of a negative impact on percentage kernel in an "on" year than does an equivalent increase in an "off" year. This implies that kernel filling is most sensitive to disruption by crop load, or fill at a slower rate, when trees are in their natural "off" phase of the biennial cycle. This "off"-phase sensitivity may have something to do with lower sink strength or lower whole-tree photoassimilation [i.e., less canopy leaf area in an "off" years and also reduced leaf assimilatory activity resulting from fewer fruit (Wood, 1988)], or even differential assimilate partitioning, of "off"-year trees. Thus, the rate of assimilate partitioning to reproductive structures in "off"year trees is not as great as that in "on"-year trees. This relationship is opposite of that embraced by most producers. It appears that one or more unknown factors is affecting kernel filling in addition to crop load and that this factor might dominate in "off" years.

These data indicate that in the case of 'Desirable', under conditions of intensive commercial management, the ReTain formulation 
of AVG can be an effective horticultural tool for increasing tree yields in "off" years of individual trees but might not be efficacious in their "on" years; hence, when viewed within the context of a full 2-year alternate bearing cycle, its value is not obvious for increasing total yield, but it might have value for moderating alternate bearing. 'Desirable' is known to be one of the few cultivars that typically drop a large percentage of developing fruit during Phase II drop (i.e., June drop), and fruit K nutrition affects this drop (Wood et al., 2010). Thus, ReTain's efficacy in commercial 'Desirable' pecan orchards is postulated to be influenced by both crop load and $\mathrm{K}$ nutrition and possibly other nutritional factors as well. Until additional information is obtained, these data support use of ReTain on well-managed 'Desirable' orchards during "off" years (i.e., often years of relatively high nutmeat prices) if a possible subsequent season roughly equivalent yield loss can be tolerated (i.e., potentially a year of relatively low nutmeat prices in the marketplace). If so, orchards might merit use of ReTain once per 2 to 3 years when crop load is low and market conditions project a year of high nut prices followed by a year of low prices. ReTain's efficacy for pecan appears problematic from a practical standpoint of increasing total nutmeat yield, because yield benefits 1 year appear to be offset by a roughly equivalent yield loss the next year. However, from the standpoint of stabilizing alternate bearing, there may be benefit in that year-to-year yield fluctuations may be smaller for 'Desirable'. It appears that one or more interacting factors affect efficacy as defined by increased fruit retention, thus meriting future research before its value as a new horticultural tool for pecan orchard managers is fully apparent.

\section{Literature Cited}

Anderson, K.K., J. Grant, J. Hasey, and W. Reil. 2006. Evaluation of ReTain for reducing pistillate flower abortion and increasing yields in 'Serr' walnuts. 9 June 2009. <http:// walnutresearch.ucdavis.edu/2006/2006_109. pdf $>$.

Beede, R.H. and V.S. Polito. 2003. Effect of ReTain on reducing pistillate flower abortion in Serr walnut. 9 June 2009. <http:// walnutresearch.ucdavis.edu/2003/2003_197. pdf $>$.

Belding, R.D. and G.R.W. Lokaj. 2002. Aminoethoxyvinylglycine treatment of peach fruit reduces ethylene production and softening. HortScience 37:1065-1068.

Bregoli, A.M., S. Scaramagli, G. Costa, E. Sabatini, V. Ziosi, S. Biondi, and P. Torrigiani. 2002. Peach (Prunus persica) fruit ripening: Aminoethoxyvinylglycine (AVG) and exogenous poly- amines affect ethylene emission and flesh firmness. Physiol. Plant. 114:472-481.

Buchner, R.P., A. Fulton, C.K. Giles, and K. Resch. 2006. ReTain applications on Tehama County 'Chandler' walnuts. 3 Oct. 2009. <http:// walnutresearch.ucdavis.edu/2006/2006_113. pdf $>$.

Byers, R.E. 1997. Peach and nectarine fruit softening following aminoethoxyvinylglycine sprays and dips. HortScience 32:86-88.

Byers, R.E. 1998a. Effects of aminoethoxyvinylglycine (AVG) on preharvest fruit drop and maturity of 'Delicious' apples. J. Tree Fruit Prod. 2:53-75.

Byers, R.E. 1998b. Effects of aminoethoxyvinylglycine (AVG) on preharvest fruit drop, maturity, and cracking of several apple cultivars. J. Tree Fruit Prod. 2:77-97.

Clayton, M., W.V. Biasi, S.M. Southwick, and E.J. Mitcham. 2000. ReTain ${ }^{\text {TM }}$ affects maturity and ripening of 'Bartlett' pear. HortScience 35: 1294-1299.

Dal-Cin, V., M. Danesin, A. Botton, A. Boschetti, A. Dorigoni, and A. Ramina. 2008. Ethylene and preharvest drop: The effect of AVG and NAA on fruit abscission in apple (Malus domestica L. Borkh). Plant Growth Regulat. 56:317-325.

Finn, G.A., A.E. Straszewski, and V. Peterson. 2007. A general stage key for describing trees and woody plants. Ann. Appl. Biol. 151:127131.

Greene, D.W. 2002. Preharvest drop control and maturity of 'Delicious' apples as affected by aminoethoxyvinylglycine (AVG). J. Tree Fruit Prod. 3:1-10.

Greene, D.W. 2005. Time of aminoethoxyvinylglycine application influences preharvest drop and fruit quality of 'McIntosh' apples. HortScience 40:2056-2060.

Greene, D.W. 2006. An update on preharvest drop control of apples with aminoethoxyvinylglycine (ReTain). Acta Hort. 727:311-319.

Greene, D.W. and J.R. Schupp. 2004. Effect of aminoethoxyvinylglycine (AVG) on preharvest drop, fruit quality, and maturation of 'McIntosh' apples. II. Effect of timing and concentration relationships and spray volume. HortScience 39: 1036-1041.

Hayama, H., M. Tatsuki, and Y. Nakamura. 2008. Combined treatment of aminoethoxyvinylglycine (AVG) and 1-methylcyclopropene (1-MCP) reduces melting-flesh peach fruit softening. Postharvest Biol. Technol. 50:228-230.

Hu, J.F., T. Fukuda, H. Ohara, E. Takahashi, and H. Matsui. 2002. Effect of AVG application on berry set of 'Kyoho' grape. J. Jpn. Soc. Hort. Sci. 68:833-838.

Hudson, W., J. Brock, S. Culpepper, W. Mitchem, and L. Wells. 2007. Georgia pecan pest management guide. Georgia Coop. Ext. Serv. Bul. No. 841.

Kays, S.J., T.F. Crocker, and R.E. Worley. 1975. Concentration dependencies of ethylene on shuck dehiscence and fruit and leaf abscission of Carya illinoensis. Agr. Food Chem. 23: 1116-1118.
Rath, A.C., I.K. Kang, C.H. Park, W.J. Yoo, and J.K. Byun. 2006. Foliar application of aminoethoxyvinylglycine (AVG) delays fruit ripening and reduces pre-harvest fruit drop and ethylene production of bagged 'Kogetsu' apples. Plant Growth Regulat. 50:91-100.

Salazar-Garciìa, S., I.J.L. Gonzailez-Duraìn, L.E. Cossio-Vargas, R.M. Torres, and C.J. Lovatt. 2006. Effect of foliar-applied plant bioregulators on 'June fruit drop,' yield and fruit size of 'Hass' avocado. Acta Hort. 727:197-202.

Schupp, J.R. and D.W. Greene. 2004. Effect of aminoethoxyvinylglycine (AVG) on preharvest drop, fruit quality, and maturation of 'McIntosh' apples. I. Concentration and timing of dilute applications of AVG. HortScience 39:1030-1035.

Shafer, W.E., C.G. Clarke, R. Fritts, and D. Woolard 1997. ReTain, a new harvest management tool for apple production. HortScience 32:507.

Smith, M.W., W. Reid, B. Carroll, and B. Cheary. 1993. Mechanical fruit thinning influences fruit quality, yield, return fruit set, and cold injury of pecan. HortScience 28:1081-1084.

Sparks, D. 1974. The alternate fruit bearing problem in pecans. Northern Nut Growers Assn. 47:80-85.

Sparks, D. and G.D. Madden. 1985. Pistillate flower and fruit abortion in pecan as a function of cultivar, time, and pollination. J. Amer. Soc. Hort. Sci. 110:219-223.

Webster, A.D., J.E. Spencer, C. Dover, and C.J. Atkinson. 2006. The influence of sprays of gibberellic acid $\left(\mathrm{GA}_{3}\right)$ and aminoethoxyvinylglycine (AVG) on fruit abscission, fruit ripening and quality of two sweet cherry cultivars. Acta Hort. 727:467-472.

Williams, M.W. 1980. Retention of fruit firmness and increase in vegetative growth and fruit-set of apples with aminoethoxyvinylglycine. HortScience 15:76-77.

Wood, B.W. 1983. Fruit thinning of pecan with ethephon. HortScience 18:53-54.

Wood, B.W. 1988. Fruiting affects photosynthesis and senescence of pecan leaves. J. Amer. Soc. Hort. Sci. 113:432-436.

Wood, B.W. 2003. Pecan production in North America. Southwest. Entomologist Suppl. 27: $1-19$.

Wood, B.W., P.J. Conner, and R.E. Worley. 2003. Relationship of alternate bearing intensity in pecan to fruit and canopy characteristics. HortScience 38:361-366.

Wood, B.W., L. Lombardini, and R.J. Herrema. 2009 Influence of aminoethoxyvinylglycine on pecan fruit retention. HortScience 44:1884-1889.

Wood, B.W., L. Wells, and F. Funderburke. 2010. Influence of elevating tree potassium on fruit-drop and yield of pecan. HortScience 45:911-917.

Yates, I.E. and D. Sparks. 1994. Anatomy differs for aborting and nonaborting pistillate flowers in pecan. J. Amer. Soc. Hort. Sci. 119:949-955.

Yates, I.E. and D. Sparks. 1995. Morphology of postpollination fruit abortion in pecan. J. Amer. Soc. Hort. Sci. 120:446-453.

Yu, Y.B., D.O. Adams, and S.F. Yang. 1979. 1aminocyclopropanecarboxylate synthase, a key enzyme in ethylene biosynthesis. Arch. Biochem. Biophys. 198:280-286. 